\title{
SHEDDING LIGHT ON THE TAXONOMIC DIVERSITY OF THE SOUTH AMERICAN MIOCENE CAIMANS: THE STATUS OF MELANOSUCHUS FISHERI (CROCODYLIA, ALLIGATOROIDEA)
}

\author{
PAULA BONA', M. VICTORIA FERNANDEZ BLANCO', TORSTEN M. SCHEYER², AND CHRISTIAN FOTH ${ }^{3}$ \\ 1División Paleontología Vertebrados, Museo de La Plata, Universidad Nacional de La Plata. Paseo del Bosque s/n. B1900FWA La Plata, Buenos Aires, Argentina. \\ Consejo Nacional de Investigaciones Científicas y Técnicas (CONICET).paulabona26@gmail.com; victoriafernandezblanco@yahoo.com.ar \\ 2Paläontologisches Institut und Museum, Universität Zürich, Karl Schmid-Strasse 4, CH-8006 Zürich, Switzerland. christian.foth@gmx.net \\ ${ }^{3}$ Department of Geosciences, University of Fribourg/Freiburg, Chemin du Musée 6 CH-1700 Fribourg, Switzerland. tscheyer@pim.uzh.ch
}

\begin{abstract}
Melanosuchus niger Spix is distributed throughout the Amazon River basin today. The extinct Melanosuchus fisheri Medina from the late Miocene of Venezuela was erected based on two almost complete, but heavily deformed skulls (the holotype MCNC 243 and the referred specimen MCZ 4336), which show morphological differences from each other. The comparison indicates that only the holotype can be referred to Melanosuchus Gray. We propose MCZ 4336 is a representative of the caimanine Globidentosuchus brachyrostris Scheyer, Aguilera, Delfino, Fortier, Carlini, Sánchez, Carrillo-Briceño, Quiroz and Sánchez-Villagra. Although the taxonomy of M. fisheri is taken into question herein, the classification of the holotype still sustains the hypothesis that the genus is registered in South America since the late Miocene.
\end{abstract}

Key words. Miocene. South America. Caimans. Amazonia. Black caiman. Caimaninae. Neogene.

Resumen. EL ESTATUS TAXONÓMICO DE MELANOSUCHUS FISHERI (CROCODYLIA, ALLIGATOROIDEA) ARROJA NUEVA LUZ SOBRE LA DIVERSIDAD DE LOS CAIMANES DEL MIOCENO DE AMÉRICA DEL SUR. Melanosuchus niger Spix se distribuye actualmente por toda la cuenca del Río Amazonas. La especie extinta Melanosuchus fisheri Medina del Mioceno tardío de Venezuela se erigió sobre la base de dos cráneos casi completos pero muy deformados (el holotipo MCNC 243 y el material referido MCZ 4336), que muestran diferencias morfológicas entre sí. La comparación indica que solo el holotipo puede ser referido a Melanosuchus Gray. Aquí se propone que MCZ 4336 es un representante del caimanino Globidentosuchus brachyrostris Scheyer, Aguilera, Delfino, Fortier, Carlini, Sánchez, Carrillo-Briceño, Quiroz and Sánchez-Villagra. Si bien la taxonomía de M. fisheri es aquí discutida, la clasificación del holotipo aún sostiene la hipótesis de que el género se registra en América del Sur desde el Mioceno tardío.

Palabras clave. Mioceno. América del Sur. Caimanes. Amazonia. Caiman negro. Caimaninae. Neógeno.

CRocodyLIA (sensu Benton and Clark, 1988) represents the crown group of neosuchian Mesoeucrocodylia (Pol et al., 2012), which probably diversified during the Late Cretaceous (Brochu, 2003). It comprises three major subclades: Alligatoroidea, Gavialoidea and Crocodyloidea. Caimaninae is a clade nested within alligatoroids that is mostly recorded in South America and includes Caiman crocodilus and all crocodylians more closely to it than to Alligator mississippiensis (Brochu, 1999). The black caiman (Melanosuchus niger Spix, 1825) is the largest extant Caimaninae alligatoroid with adult males surpassing $4-5 \mathrm{~m}$ in length and females with a mean total length of $2.8 \mathrm{~m}$ (Brazaitis and Merrit, 1973; Thorbjarnarson, 2010). Both molecular and morphological studies place M. niger closer to Caiman Spix, 1825 than to $P a-$ leosuchus Gray, 1862, forming the clade Jacarea (e.g., Brochu, 1999, 2003, 2010; Oaks, 2011; Scheyer et al., 2013; SalasGismondi et al., 2015). Nowadays, this species is widely distributed throughout the Amazon River basin, in which the biogeographical history of caimanines was significantly impacted by changes of the Pebasian (Miocene) to the Amazonian-Orinoco (Miocene-Pliocene) drainage systems (see Salas-Gismondi et al., 2016).

Although there is only one living species of Melanosuchus Gray, 1862, the genus was reported to be present since the late Miocene in South America based on two almost complete skulls (the holotype MCNC 243 and the referred specimen MCZ 4336) from the Urumaco Formation (Falcon State, Venezuela), for which the species Melanosuchus fisheri 
Medina, 1976 was erected. However, this classification was questioned (Brochu, 1999) because both skulls of M. fisheri are fairly damaged, taphonomically deformed (palatal and temporal region) and show some morphological differences from each other. Furthermore, it is particularly difficult to distinguish morphologically the holotype of $M$. fisheri from M. niger (Brochu, 1999).

The aim of this study is to re-examine the anatomy of both skulls of $M$. fisheri and compare them with other extinct and extant caimans to test the validity of the previous assignments to Melanosuchus.

Institutional Abbreviations. AMU-CURS, Colección de Paleontología de Vertebrados de la Alcaldía de Urumaco, Estado Falcón, Venezuela; FLMNH, Florida Museum of Natural History, Florida, USA; FML, Fundación Miguel Lillo, San Miguel deTucumán, Argentina; MACN, Museo Argentino de Ciencias Naturales "Bernardino Rivadavia", Ciudad Autónoma de Buenos Aires, Argentina; MCNC, Museo de Ciencias Naturales de Caracas, Caracas, Venezuela; MCZ, Museum of Comparative Zoology, Harvard University, Cambridge, USA; MFA, Museo Provincial de Ciencias Naturales "Florentino Ameghino", Santa Fé, Argentina; MG, Museo Provincial de Ciencias Naturales Dr. Ángel Gallardo, Rosario, Argentina; MLP, Museo de La Plata, La Plata, Argentina; NHMW, Naturhistorisches Museum Wien, Vienna, Austria; SMF, Senckenberg Naturmuseum Frankfurt, Frankfurt, Germany; ZSM, Zoologische Staatssammlung München, München, Germany.

\section{MATERIALS AND METHODS}

A detailed anatomical study based on a morphological comparative analysis was made on the basis of cranial material of several fossil and extant caimanines (e.g., Caiman, Melanosuchus, Globidentosuchus Scheyer et al., 2013). Specimens were examined with first-hand observations.

The two studied specimens of $M$. fisheri comprise MCNC 243 (holotype, Fig. 1.1-3), a skull lacking pterygoids, part of ectopterygoids, palatines, jugals and premaxillae, left postorbital and quadrate; and the referred specimen MCZ 4336 (Fig. 2.1-2, 5), a skull lacking pterygoids, left quadrate and quadratojugal, part of left jugal, part of basioccipital and left squamosal, and posterior two thirds of both hemimandibles. All specimens considered in this analysis are listed in the Appendix (Online Supplementary Information).

\section{DESCRIPTION AND MORPHOLOGICAL COMPARISONS}

Although partially deformed, MCNC 243 presents a caimanine-like skull with an outline resembling subadult specimens of Melanosuchus niger, i.e., a rostrum with approximately the same proportions as the extant species and orbits anteroposteriorly larger than other equal sized caimans (Figs. 1.1, 4, S1). The dorsal surface of the skull is partially eroded; however, some of the bone ornamentation can be distinguished. The sculpturing pattern is characterized by the presence of pits with different shapes and sizes irregularly distributed, more concentrated at the skull table. The skull table itself shows a straight posterior border and the squamosals are laterally elevated in occipital view (dorsal margin of the skull table curved in occipital view was listed as an autapomorphy of $M$. fisheri, see discussion below). MCNC 243 has strong "U-shaped" antorbital ridge and prefrontals contacting at midline (see also Mook, 1921: fig. 11 and discussion below). In the holotype the supratemporal fenestra are smaller and more "closed" than in subadult specimens of M. niger. In caimans (e.g., Caiman latirostris Daudin, 1802, M. niger), the supratemporal fenestra tend to get more small and closed during grow, but the size of these fenestrae also varies among specimens of the same ontogenetical stage (e.g., C. latirostris). The interorbital bridge, which was described as "arched anteroposteriorly, not concave above, thicker dorsoventrally" (Medina, 1976, p. 2), is arched in the holotype of $M$. fisheri but heavily scraped during preparation, so it is difficult to say if the concavity was originally present.

The palatal bones of MCNC 243 are damaged and eroded medially, so that sutures are largely obscured. Medially, between the premaxillae and the maxillae the suture cannot be traced because the bony surface of the palate is not preserved here, so the presence of the character "vomer exposed in palatal view" (diagnostic feature of the extant Melanosuchus niger) cannot be specified in this specimen. The size and shape of the suborbital fenestra are similar to M. niger and, as in this species, MCNC 243 also has 13 maxillary alveoli (preserved and counted in the left maxilla, but inferred on the right side, Fig. 1.2). No remains of the lower jaw are preserved in the holotype.

In contrast, the specimen MCZ 4336 has a relative small and more robust skull with a wider and rounded rostrum (Fig. 2.1-2). Contrary to MCNC 243, the cranial ornamenta- 
(1)

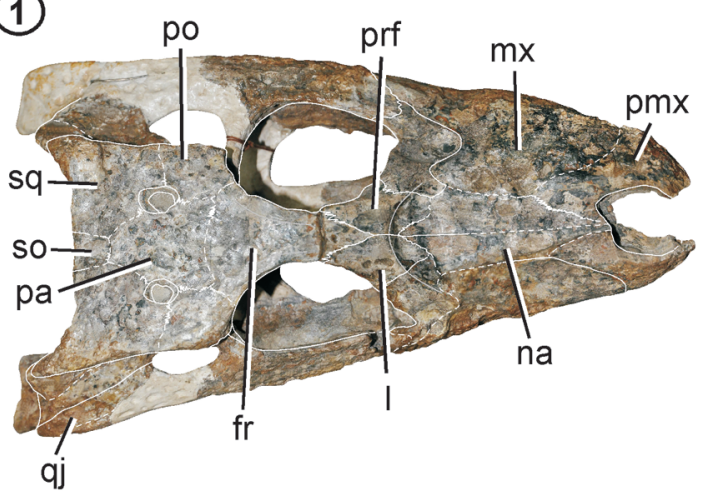

(2)

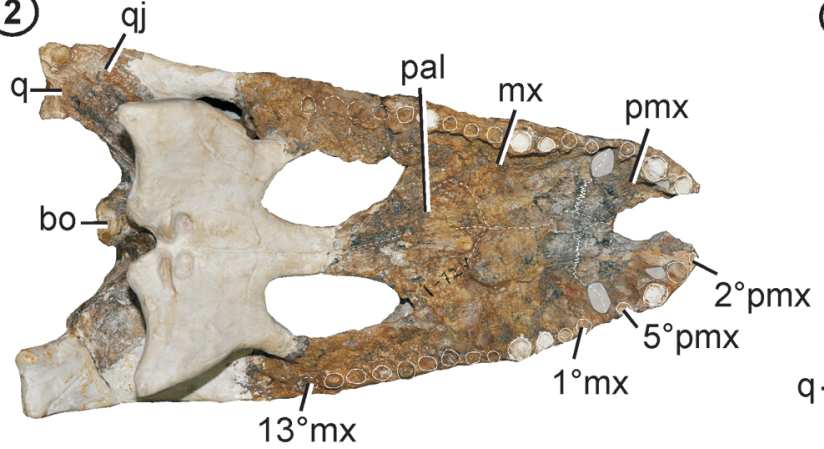

(3)

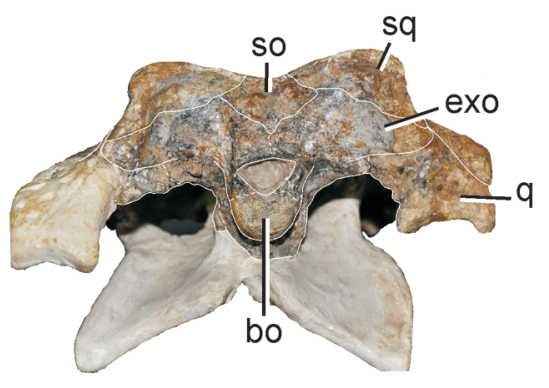

(4)

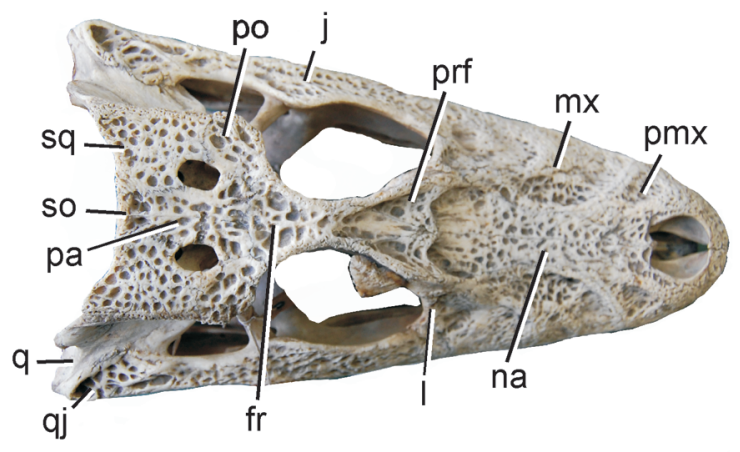

(5)

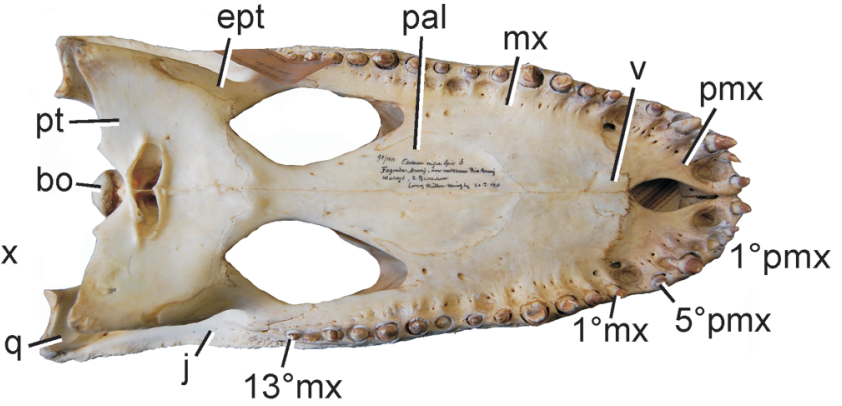

(6)

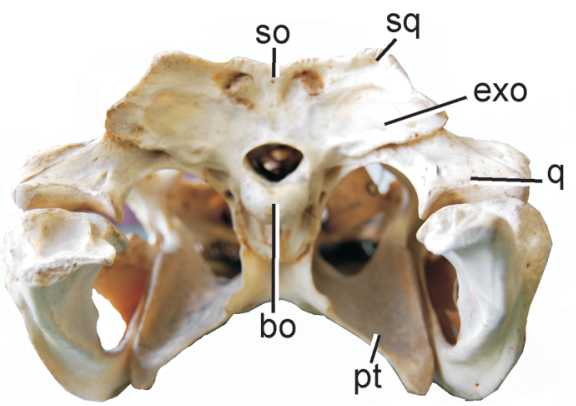

Figure 1. 1-3, Skull of Melanosuchus fisheri MCNC 243; 1, dorsal view; 2, ventral view; 3, occipital view. 4-6, Skull of Melanosuchus niger; 4-5, ZSM 90/1911; 6, ZSM 77/1911; 4, dorsal view; 5, ventral view; 6, occipital view. Abbreviations: bo, basioccipital; ept, ectopterigoyd; exo, exoccipital (exoccipital-opistothic complex); fr, frontal; j, jugal; l, lacrimal; mx, maxilla; na, nasal; pa, parietal; pal, palatine; pmx, premaxilla; po, postorbital; prf, prefrontal; pt, pterygoid; q, quadrate; qj, quadratojugal; so, supraoccipital; sq, squamosal; v, vomer; $2^{\circ}-5^{\circ} \mathrm{pmx}, 2^{\text {nd }}$ to $5^{\text {th }}$ premaxillary alveoli; $1^{\circ}-13^{\circ} \mathrm{mx}, 1^{\text {st }}$ to $13^{\text {th }}$ maxillary alveoli. Scale bars $=5 \mathrm{~cm}$.

tion is given by sub circular pits uniformly distributed all over the surface of the bones. Interorbital ridges are absent and preorbital ridges are weak and practically absent at the maxilla. In MCZ 4336, the frontals have a different morphology than in extant Melanosuchus and Caiman species with extremely short anterior processes, probably articu- lating in a V-shaped suture with the prefrontals rostrally. The supraoccipital is widely exposed on the skull roof and, as in other caimans, it excludes the parietal from the posterior edge of the skull table. As in MCNC 243, the interorbital bridge is crushed (Scheyer and Delfino, 2016) so that its original morphology cannot be verified. In contrast to MCNC 

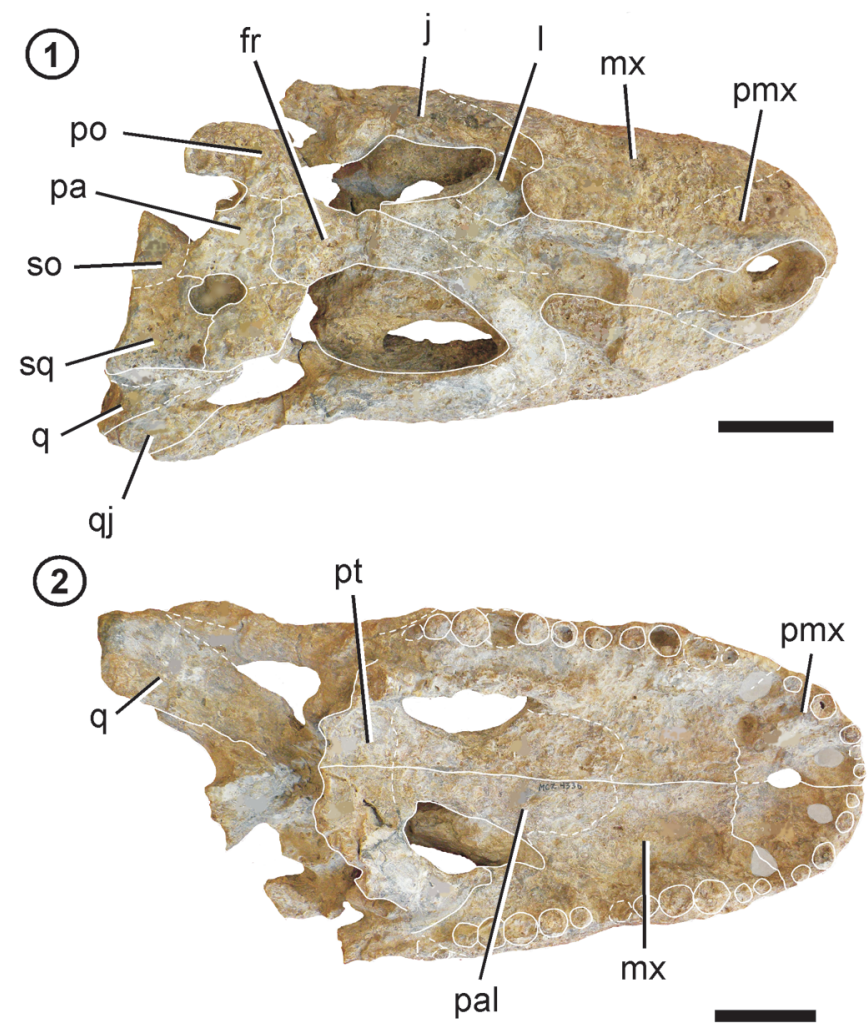

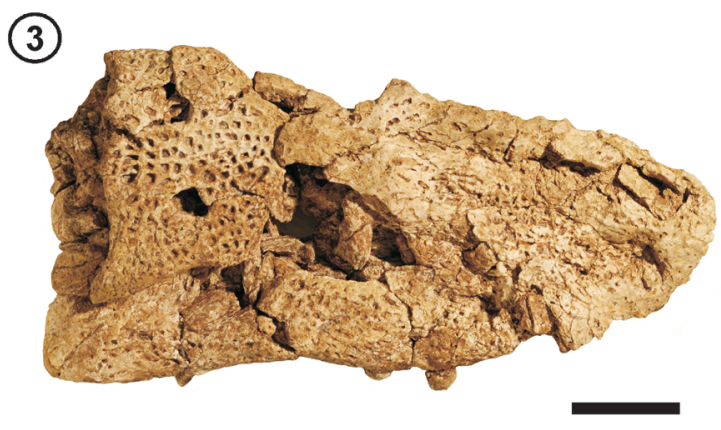

(4)

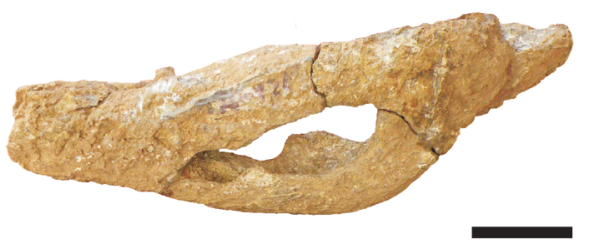

(5)

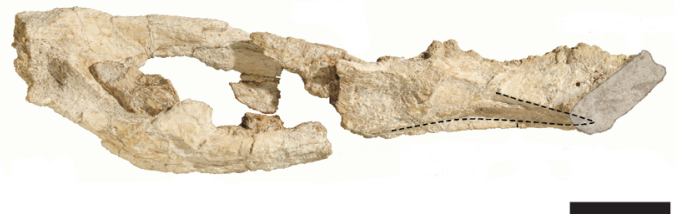

Figure 2. 1-2, 5, MCZ 4336; 1, dorsal view of the skull; 2, ventral view of the skull; 5, lateral view of left hemimandible. 3-4, Globidentosuchus brachyrostris AMU-CURS-222; 3, dorsal view of the skull; 4, lateral view of right hemimandible (mirrored). Abbreviations: fr, frontal; j, jugal; I, lacrimal; mx, maxilla; pa, parietal; pal, palatine; pmx, premaxilla; po, postorbital; pt, pterygoid; q, quadrate; qj, quadratojugal; so, supraoccipital; sq, squamosal. Scale bars $=5 \mathrm{~cm}$.

243 and M. niger, MCZ 4336 possesses a reduced number of maxillary alveoli (11 partially preserved on the left side; Fig 2.2). The external mandibular fenestra is large and low, but given the distortion of the material it might have been dorsoventrally higher in life (Fig. 2.5). There are at least two posterior teeth preserved in the right mandible of this specimen. They are robust with sub-spherical crowns, contrasting with the teeth morphology present in extant crocodylians (Fig. 2.5). MCZ 4336 also has preserved posterior fragments of both hemimandibles, but they are not very informative.

\section{DISCUSSION}

Melanosuchus is nested within the taxon Caiman in morphology-based phylogenetic analyses (e.g., Brochu 2011, Salas-Gismondi et al., 2015; Hastings et al., 2016), while molecular studies found Melanosuchus as sister group to the Caiman clade (Poe, 1996; Oaks, 2011). Thus, based on this discrepancy, we provisionally retain Melanosuchus as a valid genus until more conclusive studies are conducted on the taxonomy of South American alligatorids.

The taxonomic validity of Melanoschus fisheri was based on a combination of morphological features taken from both MCNC 243 and MCZ 4336, considered by Medina (1976) as the same taxon by their overall morphological similarities and their similar skull proportions. After detailed anatomical comparisons, we conclude, however, that these two specimens do not represent the same taxon, as they show a number of significant morphological differences, namely in the skull ornamentation, number of maxillary teeth, the occurrence of interorbital and preorbital ridges, and the shape of the frontal and supraoccipital. This outcome has far reaching consequences for the diagnosis of the species M. fisheri (see below), which was based on the two specimens (Medina, 1976).

The holotype of $M$. fisheri preserves several skull fea- 
tures that can be found in M. niger and other jacarean caimanines or fall within its intraspecific morphological range of variation. Like M. niger (Fig. S1), MCNC 243 has anteroposteriorly longer orbits (only present in $M$. niger) than other similar sized caimans and shows also strong "U-shaped" antorbital ridges (also present in C. latirostris and C. crocodilus). Although partially deformed, the proportions of the rostrum of the holotype is very similar to that of $M$. niger. The prefrontals of MCNC 243 are contacting at the midline as is the case in some specimens of $M$. niger (e.g., ZSM 73/1911; ZSM 74/1911; ZSM 77/1911; ZSM 90/1911; see also Mook, 1921: fig. 11). Regarding the skull table, MCNC 243 shows a straight posterior border as was described by Medina (1976). However, this feature varies individually within $M$. niger with the posterior margin being straight (e.g., FLMNH 53600; SMF 30102; SMF 40172; ZSM 46/1911; ZSM 85/1911) to deeply curved, being "U-"(e.g., SZM 12/1911) or "V-shaped" (e.g., SZM 14/1911). Another important feature shared by the holotype MCNC 243 and large specimens of the extant $M$. niger is the dorsolateral elevation of the squamosals at the dorsal margin of the occipital table in occipital view (Fig. 1.3, 6). They further conform in the number of maxillary teeth (13), also present in $C$. latirostris (and contrary to Caiman yacare, which presents 14 maxillary teeth). In extant Caimaninae, the latter character is conserved throughout the whole ontogeny and not affected by individual variation. The exposure of the vomer at the palate, contacting with premaxillae and maxillae is a distinctive feature of Melanosuchus niger (Mook, 1921; Fig. 1.5), but unfortunately, the preservation of the damaged palatal region in the holotype of $M$. fisheri (with sutures largely obscured), allows only an ambiguous interpretation of this feature (Fig. 1.2). However, based on the number of similarities listed above, MCNC 243 can be confidently assigned to jacarean caimanines, sharing similarities (e.g., enlarged orbits, rostral shape) with $M$. niger. Neither its affiliation to Melanosuchus nor its classification as its own species is possible to support at the moment, as a number of shared characters listed are also present in other jacarean caimanines, while most diagnostic features of $M$. fisheriare based on the referred specimen (MCZ 4336), which differs from both MCNC 243 and Melanosuchus (see above). The lack of diagnostic features in the holotype MCNC 243 (because of its poor preservation, especially at the orbital and rostral portions) prevents a conclusive decision regarding the taxonomic status of Melanosuchus fisheri and therefore this taxon could be regarded as a nomen dubium. However, there are some cranial shape differences and similarities among MCNC 243 with extant caimanine taxa (e.g., Caiman crocodilus/C. jacare and C. latirostris/Melanosuchus niger, respectively), which can offer new information on the taxonomic status of $M$. fisheri through a geometric morphometric analysis (Foth et al., 2017).

Comparing the referred specimen MCZ 4336 with other neogene caimanines, it shows the same general morphology, outline, proportions and skull ornamentation as Globidentosuchus brachyrostris. This taxon is a basal caimanine that comes from the same levels of the Urumaco Formation (Scheyer et al., 2013; Scheyer and Delfino, 2016; Fig. 2.3-4). Some of the original diagnostic characters of $M$. fisheri, such as "skull more robust; snout deeper heavier; preorbital ridges on snout faint rather than strong" (Medina, 1976 , p. 2), are based on this specimen and fit the morphology of $G$. brachyrostris. As in the latter species, MCZ 4336 is a relative small caimanine with an $U$-shaped, short and wide skull (and rostrum); deep and robust mandibles; weak preorbital ridges and absent interorbital ridges; frontals without anterior processes, articulating in a Vshaped suture with the prefrontals rostrally; rectangularshaped prefrontals, meeting in midline; supraoccipital well exposed on skull roof, excluding the parietal from posterior skull table edge; sub-spherical or globular posterior mandibular teeth (there are at least two globular teeth preserved in the right mandible of MCZ 4336); superior edge of coronoid slopes almost horizontally, and margin of orbit flush with skull surface (Fig. 2). Furthermore, the bone configuration of the skull roof of MCZ 4336 is very similar to G. brachyrostris (see Scheyer et al., 2013; Hastings et al., 2016), as the supraoccipital is crescent-shaped and more exposed on the skull roof of MCZ 4336. In addition, the mandibular fenestra of MCZ 4336 is large and probably low as in G. brachyrostris, but given the distortion of the material the fenestra might have been higher in life. Based on these features we refer MCZ 4336 to G. brachyrostris. Finally, the morphology of both posterior fragments of hemimandibles of MCZ 4336 also resembles that of $G$. brachyrostris (Fig. 2.4, 5; see also Scheyer and Delfino, 2016). 


\section{CONCLUSIONS}

According to the discussed morphological evidence, we assign MCZ 4336 to the basal caimanine Globidentosuchus brachyrostris, whereas the holotype specimen of $M$. fisheri (MCNC 243) shows clear affinities with jacarean caimanines, and most likely can be referred to the genus Melanosuchus. However, at this point there are no morphological characters that can be used to assign this material to its own species and to distinguish it from $M$. niger. Further comparisons with other jacarean caimans including geometric morphometric analyses are needed to verify its finer differences and similarities with Melansuchus niger (Foth et al., 2017). Up to now, one taxonomical hypothesis is to consider Melanosuchus fisheri as a nomen dubium and assign MCNC 243 to Melanosuchus sp. on the basis of the rostral shape and the enlarged orbits (Mook, 1921; Kälin, 1933). Accordingly, material previously assigned to Caimaninae aff. Melanosuchus fisheri, such as AMU-CURS-234 (see Scheyer and Delfino, 2016), should be reassigned to Melanosuchus sp. as well.

Despite these uncertainties on the taxonomic status of M. fisheri, our study corroborates that Melanosuchus and other jacarean caimanines were already present in South America since the late Miocene (Bona et al., 2014), which is further supported by molecular clock estimations (Oaks, 2011). Together with G. brachyrostris and other caimanines (e.g., Caiman brevirostris Souza-Filho, 1987, Mourasuchus arendsi Bocquentin-Villanueva, 1984, Purussaurus mirandai Aguilera, Riff and Bocquentin-Villanueva, 2006, Purussaurus brasiliensis Barbosa-Rodrigues, 1892; see Scheyer et al., 2013; Salas-Gismondi et al., 2015; Scheyer and Delfino, 2016), the black caiman could have formed part of the crocodylian assemblage that evolved in Amazonia during the Neogene.

\section{ACKNOWLEDGMENTS}

TMS thanks R. Salas-Gismondi (Smithsonian Tropical Research Institute STRI) and M. Delfino (Univ. Torino) for fruitful discussions, J. Carrillo (AMU), and R. Sánchez (STRI) for their support in Venezuela. $\mathrm{H}$. Moreno (MCNC) is thanked for access to the holotype specimen of $M$. fisheri and the Alcaldía Bolivariana del Municipio Urumaco is thanked for access to comparative caimanine material from Urumaco Formation. This work was supported by the Swiss National Science Foundation (grant no. 205321-162775 to TMS), the Deutsche Forschungsgemeinschaft (RA 1012/12-1 to CF), the Deutscher Akademischer Austauschdienst (grant nº. 91546784 to CF) and the Agencia Nacional de Promoción Científica y Tecnológica (ANPCYT PICT-2012-0748).

\section{REFERENCES}

Aguilera, O.A., Riff, D., and Bocquentin-Villanueva, J. 2006. A new giant Purussaurus (Crocodyliformes, Alligatoridae) from the Upper Miocene Urumaco Formation, Venezuela. Journal of Systematic Palaeontology 4: 221-232.

Barbosa Rodrigues, B. 1892. Les Reptiles fossiles de la vallée de I'Amazone. Vellosia-Contribuicões do Museu Botanico do Amazonas 2: 41-46.

Benton, M.J., and Clark, J.M. 1988. Archosaur phylogeny and the relationships of the Crocodylia. In: M.J. Benton (Ed.), The Phylogeny and Classification of the the Tetrapods, Volume 1: Amphibians, Reptiles, Birds. Systematics Association Special Volume No. 35A. Clarendon Press, Oxford, p. 295-338.

Bocquentin-Villanueva, J.C. 1984. Un nuevo Nettosuchidae (Crocodylia, Eusuchia) proveniente da la Formación Urumaco (Mioceno Superior), Venezuela. Ameghiniana 21: 3-8.

Bona, P., Starck, D., Galli, C., Gasparini, Z., and Reguero, M. 2014. Caiman cf. latirostris (Alligatoridae, Caimaninae) in the late Miocene Palo Pintado Formation, Salta Province, Argentina: paleogeographic and paleoenvironmental considerations. Ameghiniana 51: 26-36.

Brazaitis, P., and Merritt, D.A. 1973. The identification of living crocodilians. Zoologica 58: 59-104.

Brochu, C.A. 1999. Phylogenetics, taxonomy, and historical biogeography of Alligatoroidea. Journal of Vertebrate Paleontology 19: 9-100.

Brochu, C.A. 2003. Phylogenetic approaches toward crocodylian history. Annual Review of Earth and Planetary Science 31: 357397.

Brochu, C.A. 2010. A new alligatorid from the lower Eocene Green River Formation of Wyoming and the origin of caimans. Journal of Vertebrate Paleontology 30: 1109-1126.

Brochu, C.A. 2011. Phylogenetic relationships of Necrosuchus ionensis Simpson 1937 and the early history of caimanines. Zoological Journal of the Linnean Society 163: 228-256.

Daudin, F.M. 1802. Histoire naturelle, générale et particulière des Reptiles. F. Dufart, Paris, $452 \mathrm{p}$.

Foth, C., Fernandez Blanco, M.V., Bona, P., and Scheye T.M. 2017. Cranial shape variation in jacarean caimanines (Crocodylia, Alligatoroidea) and its implications in the taxonomic status of extinct species: The case of Melanosuchus fisheri. Journal of Morphology. DOI: 10.1002/jmor.20769.

Gray, J.E. 1862. A synopsis of the species of alligators. Annals and Magazine of Natural History 3: 327-331.

Hastings, A., Reisser, M., and Scheyer, T.M. 2016. Character evolution and the origin of Caimaninae (Crocodylia) in the New World tropics: new evidence from the Miocene of Panama and Venezuela. Journal of Paleontology 90: 317-332.

Kälin, J.A. 1933. Beiträge zur vergleichenden Osteologie des Crocodilidenschädels. Zoologisches Jahrbuch 57: 535-714.

Medina, C.J. 1976. Crocodilian from the Late Tertiary of Northwestern Venezuela: Melanosuchus fisherisp. nov. Breviora 438 : $1-14$.

Mook, C.C. 1921. Skull characters of recent Crocodilia: with notes on the affinities of the recent genera. Bulletin of the American Museum of Natural History 44: 123-268.

Oaks, J.R. 2011. A time-calibrated species tree of Crocodylia reveals a recent radiation of the true crocodiles. Evolution 65: 32853297.

Poe, S. 1996. Data set incongruence and the phylogeny of crocodilians. Systematic Biology 45: 393-414.

Pol, D., Leardi, J.M., Lecuona, A., and Krause, M. 2012. Postcranial 
anatomy of Sebecus icaeorhinus (Crocodyliformes, Sebecidae) from the Eocene of Patagonia. Journal of Vertebrate Paleontology 32: 328-354.

Salas-Gismondi, R., Flynn, J., Baby, P., Tejada-Lara, J.V., Claude, J., and Antoine, P.O. 2016. A new 13 Million year old gavialoid crocodylian from proto-Amazonian mega-wetlands reveals parallel evolutionary trends in skull shape linked to longirostry. PLoS One 11: e0152453.

Salas-Gismondi, R., Flynn, J., Baby, P., Tejada-Lara, J.V., Wesselingh, F.P., and Antoine, P.O. 2015. A Miocene hyperdiverse crocodylian community reveals peculiar trophic dynamics in protoAmazonian mega-wetlands. Proceedings of the Royal Society of London B: Biological Sciences 282: 20142490.

Scheyer, T.M., and Delfino, M. 2016. The late Miocene caimanine fauna (Crocodylia: Alligatoroidea) of the Urumaco Formation, Venezuela. Palaeontologia Electronica 19.3.48A: 1-57.

Scheyer, T.M., Aguilera, O.A., Delfino, M., Fortier, D.C., Carlini, A.A., Sánchez, R., Carrillo-Briceño, J.D., Quiroz, L., and Sánchez-ViIlagra, M.R. 2013. Crocodylian diversity peak and extinction in the late Cenozoic of the northern Neotropics. Nature Communications 4: 1907.

Souza-Filho, J.P. 1987. Caiman brevirostris sp. nov., um novo Alligatoridae da Formação Solimões (Pleistoceno) do Estado do Acre, Brasil. X Congresso. Brasileiro de Paleontologia (Rio de Janeiro), Anais: $173-180$.
Spix, J.B. 1825. Animalia nova sive Species novae lacertarum quas in itinere per Brasiliam annis MDCCCXVII-MDCCCXX jussu et auspiciis Maximiliani Josephi I. Bavariae Regis suscepto collegit et descripsit Dr. J.B. de Spix. T.O. Weigel, Leipzig, 26 p.

Thorbjarnarson, J.B. 2010. Black Caiman Melanosuchus niger. In: S.C. Manolis, and C. Stevenson (Eds.), Crocodiles. Status Survey and Conservation Action Plan. Third Edition. Crocodile Specialist Group. Darwin, Australia, p. 29-39.

doi: 10.5710/AMGH.08.06.2017.3103

Submitted: March 215t, 2017

Accepted: June $8^{\text {th }}, 2017$

Published online: June $10^{\text {th }}, 2017$ 